This item was submitted to Loughborough's Research Repository by the author.

Items in Figshare are protected by copyright, with all rights reserved, unless otherwise indicated.

\title{
Reporting aid flows for water supply and sanitation: official development
} assistance

PLEASE CITE THE PUBLISHED VERSION

http://dx.doi.org/10.2166/washdev.2013.058

PUBLISHER

(C) IWA Publishing

VERSION

AM (Accepted Manuscript)

LICENCE

CC BY-NC-ND 4.0

REPOSITORY RECORD

Cotton, Andrew P.. 2019. "Reporting Aid Flows for Water Supply and Sanitation: Official Development Assistance". figshare. https://hdl.handle.net/2134/12845. 
This item was submitted to Loughborough's Institutional Repository (https://dspace.lboro.ac.uk/) by the author and is made available under the following Creative Commons Licence conditions.

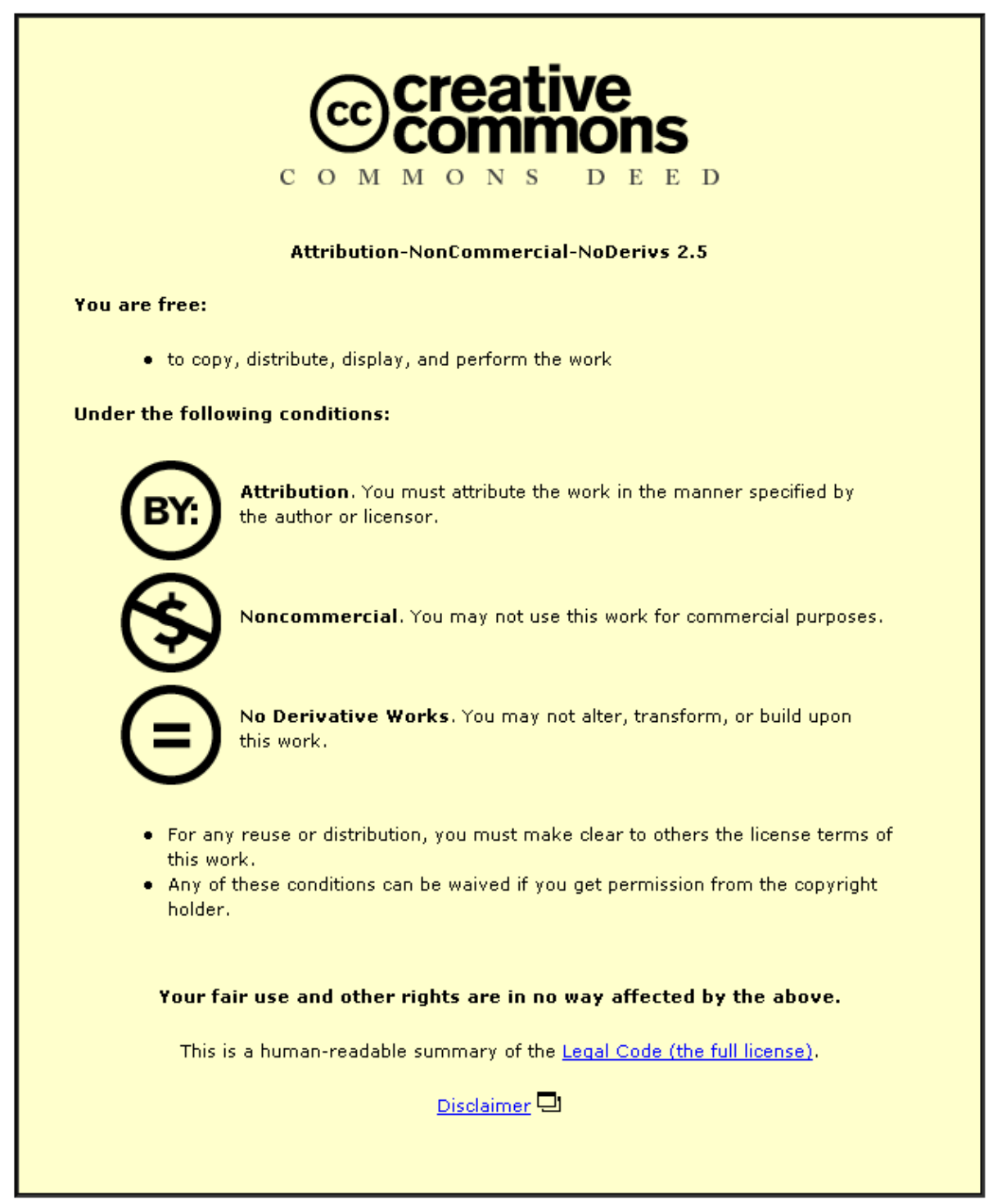

For the full text of this licence, please go to: http://creativecommons.org/licenses/by-nc-nd/2.5/ 


\title{
Reporting Aid Flows for Water Supply and Sanitation: Official Development Assistance
}

A Cotton (corresponding Author), WEDC, Loughborough University, Loughborough LE11 3TU

\author{
UK, a.p.cotton@lboro.ac.uk
}

\begin{abstract}
Current resource allocations for water supply and sanitation are far below those required to meet basic needs particularly in low income countries. Many organisations supporting advocacy and arguing for change make use of the primary statistical data for Official Development Assistance (ODA) which measures donor aid flows to the sector. Important changes have taken place to the way ODA is reported including disaggregation between aid flows for water supply and aid flows for sanitation from 2010 onwards.

This paper reports findings from a Consultative Group regarding issues requiring clarification for the revised codes to be applied consistently. These include: disaggregation of water and sanitation from within integrated water sector projects; disaggregation of water and sanitation components from projects in other sectors; clarity on working definitions of "large and basic" when reporting water and sanitation projects; capacity development that directly supports implementation; and recording the transition from projects to programme-based aid. Case studies drawn from donors' reporting of ODA are used to illustrate key issues for users of ODA statistical information who aim to capture data on aid flows to the water sector.
\end{abstract}

$\begin{array}{ll}\text { ABBREVIATIONS } & \text { AND ORGANISATIONS } \\ \text { CRS } & \text { Creditor Reporting System } \\ \text { DAC } & \text { Development Assistance Committee } \\ \text { EU } & \text { European Union } \\ \text { GLAAS } & \text { Global Annual Assessment of Drinking Water and Sanitation } \\ \text { MDGs } & \text { Millennium Development Goals } \\ \text { NGO } & \text { Non government organisation } \\ \text { ODA } & \text { Official Development Assistance } \\ \text { WHO } & \text { World Health Organisation } \\ \text { WASH } & \text { Water supply, sanitation and hygiene }\end{array}$

\section{INTRODUCTION}

International context

Globally, 884 million people are without improved sources of drinking water and 2.6 billion people do not use improved sanitation (WHO/UNICEF 2010). The Global Annual Assessment of Sanitation and Drinking Water report (GLAAS 2010) presents a bleak picture of the external financial resources flowing to the sector as measured by Official Development Assistance (ODA). 35 out of the 37 countries surveyed reported that financial flows were insufficient to achieve the 
Millennium Development Goal (MDG) target for sanitation, with 32 having insufficient to reach the drinking water target. In 2008, development aid for sanitation and drinking water amounted to US\$7.4 billion (GLAAS 2010) whereas global cost estimates to reach the MDG target vary enormously from US\$6.7 billion to US\$75 billion per year depending on the assumptions made (WELL 2005).

Sanitation is one of the most off-track of the MDG targets; the International Year of Sanitation in 2008 drew attention to the lack of progress in sanitation and to the dearth of reliable data particularly on financial flows. Where data have been collected, it is clear that financing for sanitation is low in comparison to water (EU Water Initiative Africa Working Group 2008). This helped to provide the impetus to improve the reporting of ODA through disaggregating data for sanitation from water supply.

Primary statistical data for Official Development Assistance is widely used for sector advocacy, policy development and pursuing accountability at global, regional and national levels in the water sector and provides much of the evidence on financial flows for major reports in the sector such as GLAAS (2010). Similarly, WaterAid (2011) used ODA data to present a hard-hitting analysis of the distribution of aid flows for drinking water supply and sanitation to recipient countries, concluding that for water supply and sanitation, aid flows were both insufficient and weakly correlated with need.

The purpose of this paper is to outline recent changes to the way that donors report their ODA for the water sector, which now disaggregates between aid flows for water supply and aid flows for sanitation, and to illustrate important issues that arise in capturing these data. The paper is relevant to organisations and individuals who make use of and interpret the data provided by the OECD Development Assistance Committee (DAC) Creditor Reporting System (CRS) data for their own research, advocacy and policy development. It offers guidance on where to look for data and illustrates how the ODA for different types of projects and programmes is classified and reported through the Creditor Reporting System. The paper is also relevant for reporters of statistical data who are applying the purpose codes to their organisations' ODA. The work contributes to the higher level objective of improving the overall quality of data in the water sector through promoting greater consistency of both the reporting and interpretation of data on ODA. The work is based on research commissioned by the Africa Working Group of the EU Water Initiative for the development of guidance for those applying the revised purpose codes (OECD Development Co-operation Directorate 2010a).

\section{About the OECD DAC Creditor Reporting System}

The OECD Development Assistance Committee collects statistics on aid flows at activity level from the bilateral and multilateral donors who are members of the DAC through the Creditor Reporting System. The data collection is based on a standard methodology and agreed definitions using a set of 'purpose codes' for different sectors and subsectors (OECD Development Co-operation Directorate 2010b). OECD DAC data are the unique sources for official, standard and comparable statistics on Official Development Assistance and can be used to analyse trends and compare the efforts of donors. The database (OECD Development Cooperation Directorate n.d) is searchable by donor, recipient country, region, sub-region and aidtype for a particular reference year.

For data up to and including 2009, the OECD Creditor Reporting System did not support donors to disaggregate expenditure on water supply and sanitation. This issue was brought to the fore within the context of the preparation work for the Global Annual Assessment of Sanitation and Drinking Water (GLAAS 2010) and a study of aid mapping commissioned by the Africa Working 
Group of the European Union (EU) Water Initiative (EU Water Initiative Africa Working Group 2008). It was felt that the water and sanitation sector, as reported under the DAC5 code 140, had undergone major developments in recent years. This led to a change both in donors' activities and in reporting needs, which were not felt to be adequately covered by the pre-2010 CRS purpose codes. Some adaptations were required to keep abreast of these changes and to facilitate transparency in sector spending for water supply and sanitation.

A proposal to revise the purpose codes for water was developed by the Africa Working Group of the European Water Initiative and was submitted to the OECD DAC Working Party on Statistics in May 2009 (OECD Development Co-operation Directorate 2009) on behalf of the Governments of the United Kingdom and Austria with the support of UN Water and the Africa Working Group of the European Water Initiative. The key aspect of the proposal, which was accepted, enabled donors to report ODA for water supply and sanitation separately. The purpose codes for water and sanitation were revised taking effect in 2011 reporting on 2010 flows.

\section{METHODOLOGY}

Following the adoption of the revised purpose codes for water (OECD Development Co-operation Directorate 2010b), a consultative group was established from donor and civil society members of the Africa Working Group of the European Water Initiative, including representation from the OECD Development Co-operation Directorate, to identify likely issues that would require further clarification in order for the revised codes to be applied consistently. The 13 members of the consultative group also acted as key informants. The following process was adopted.

- OECD documents were reviewed in order to identify potential issues to explore with key informants.

- A questionnaire and interview guide was developed for use with key informants to determine which issues in the new purpose codes required guidance and clarification.

- The questionnaire and a short background document were circulated; the key informants responded either by returning the questionnaire by email or by telephone interview.

- From the responses, a list of the main issues requiring guidance was established and the current practices of individual donors in reporting their aid was established.

- Requests to donors were made for case study material to illustrate the main issues. Austria, the Netherlands and the UK together provided summary details of several hundred projects from their reporting databases to illustrate the key issues requiring guidance for reporting and interpreting ODA statistical data.

- A shortlist of projects was identified with each project being subject to three stages of analysis:

- review of objectives, key outputs and project summaries;

- budget analysis to determine allocations to different sector and sub-sector components; and

- review of detailed project descriptions with respect to the revised purpose codes.

- 13 projects in total were selected for inclusion in the guidance note (OECD Development Directorate 2010a) and form the basis for the results presented in this paper.

\section{RESULTS}

\section{Revised Purpose Codes and DAC definition of water supply and sanitation}

For the purpose of reporting ODA, the water sector is divided into the sub-sectors shown in Table 1. This classification now disaggregates between aid flows for water supply and aid flows for 
sanitation. The definition of aid for water supply and sanitation excludes dams and reservoirs primarily for irrigation and hydropower and activities related to river transport which are recorded elsewhere in the classification (aid to agriculture, energy and transport respectively). DAC statistics classify humanitarian aid as a separate category (the main purpose being to save lives in an emergency context), and do not record the ultimate sector of destination of humanitarian interventions (water, health, education, etc.).

Table 1. Aid to the water supply and sanitation sector: definition and sub-sectors

\begin{tabular}{|c|c|c|}
\hline $\begin{array}{l}\text { CRS } \\
\text { Code }\end{array}$ & Sub-sector & Description \\
\hline 14010 & $\begin{array}{l}\text { Water sector policy and } \\
\text { administrative management }\end{array}$ & $\begin{array}{l}\text { Water sector policy and governance, including legislation, regulation, planning } \\
\text { and management as well as transboundary management of water; institutional } \\
\text { capacity development; activities supporting the Integrated Water Resource } \\
\text { Management approach }\end{array}$ \\
\hline 14015 & $\begin{array}{l}\text { Water resources conservation } \\
\text { (including data collection) }\end{array}$ & $\begin{array}{l}\text { Collection and usage of quantitative and qualitative data on water resources; } \\
\text { creation and sharing of water knowledge; conservation and rehabilitation of } \\
\text { inland surface waters (rivers, lakes etc.), ground water and coastal waters; } \\
\text { prevention of water contamination. }\end{array}$ \\
\hline 14020 & $\begin{array}{l}\text { Water supply and sanitation - large } \\
\text { systems }\end{array}$ & $\begin{array}{l}\text { Programmes where components according to } 14021 \text { and } 14022 \text { cannot be } \\
\text { identified. When components are known, they should individually be reported } \\
\text { under their respective purpose codes: water supply [14021], sanitation [14022], } \\
\text { and hygiene [12261]. }\end{array}$ \\
\hline 14021 & Water supply - large systems & $\begin{array}{l}\text { Potable water treatment plants; intake works; storage; water supply pumping } \\
\text { stations; large scale transmission / conveyance and distribution systems. }\end{array}$ \\
\hline 14022 & Sanitation - large systems & $\begin{array}{l}\text { Large scale sewerage including trunk sewers and sewage pumping stations; } \\
\text { domestic and industrial wastewater treatment plants. }\end{array}$ \\
\hline 14030 & $\begin{array}{l}\text { Basic drinking water supply and } \\
\text { basic sanitation }\end{array}$ & $\begin{array}{l}\text { Programmes where components according to } 14031 \text { and } 14032 \text { cannot be } \\
\text { identified. When components are known, they should individually be reported } \\
\text { under their respective purpose codes: water supply [14031], sanitation [14032], } \\
\text { and hygiene [12261]. }\end{array}$ \\
\hline 14031 & Basic drinking water supply & $\begin{array}{l}\text { Rural water supply schemes using handpumps, spring catchments, gravity-fed } \\
\text { systems, rainwater collection and fog harvesting, storage tanks, small distribution } \\
\text { systems typically with shared connections/points of use. Urban schemes using } \\
\text { handpumps and local neighbourhood networks including those with shared } \\
\text { connections. }\end{array}$ \\
\hline 14032 & Basic sanitation & $\begin{array}{l}\text { Latrines, on-site disposal and alternative sanitation systems, including the } \\
\text { promotion of household and community investments in the construction of these } \\
\text { facilities. (Use code } 12261 \text { for activities promoting improved personal hygiene } \\
\text { practices.) }\end{array}$ \\
\hline 14040 & River basins' development & $\begin{array}{l}\text { Infrastructure focused integrated river basin projects and related institutional } \\
\text { activities; river flow control; dams and reservoirs [excluding dams primarily for } \\
\text { irrigation (31140) and hydropower (23065) and activities related to river transport } \\
\text { (21040)]. }\end{array}$ \\
\hline 14050 & Waste management / disposal & $\begin{array}{l}\text { Municipal and industrial solid waste management, including hazardous and toxic } \\
\text { waste; collection, disposal and treatment; landfill areas; composting and reuse. }\end{array}$ \\
\hline 14081 & $\begin{array}{l}\text { Education and training in water } \\
\text { supply and sanitation }\end{array}$ & Education and training for sector professionals and service providers. \\
\hline
\end{tabular}

Source: OECD Development Co-operation Directorate (2010b)

Whilst the majority of users are likely to abstract aggregate values of ODA reported against the purpose codes in Table 1, it is possible to mine more deeply into the data to view the individual projects reported by each DAC member.

Table 2 identifies the issues which respondents identified as requiring clarification and guidance to ensure consistent application and use of the data. Firstly, for those who apply the CRS codes 
to their organisations' ODA; and secondly for those who use and interpret the data for research, policy development and advocacy. .

\section{Table 2. Issues for clarification and Guidance}

\begin{tabular}{|c|c|c|}
\hline & Issue & Commentary \\
\hline 1 & $\begin{array}{l}\text { Disaggregation of } \\
\text { water and sanitation } \\
\text { a) in integrated } \\
\text { water sector } \\
\text { projects } \\
\text { b) as components in } \\
\text { projects in other } \\
\text { sectors }\end{array}$ & $\begin{array}{l}\text { a) The difficulty of disaggregating the reporting of integrated programmes, in } \\
\text { particular where a conscious effort has been made to integrate aid components } \\
\text { across the area covered by the } 140 \text { Codes. This covers the situation where the } \\
\text { distinction could be made between "large and basic" but not between "water } \\
\text { supply and sanitation". } \\
\text { b) More broadly, disaggregating water and sanitation from within projects and } \\
\text { programmes in other-than the water sector }\end{array}$ \\
\hline 2 & $\begin{array}{l}\text { Definition of "large } \\
\text { and basic" water } \\
\text { and sanitation } \\
\text { projects }\end{array}$ & $\begin{array}{l}\text { The current Notes to the } 140 \text { Purpose Codes are unclear with respect to a) the } \\
\text { technology and b) the scale of application, for example } \\
\text { - } \quad \text { where a basic technology such as on-site sanitation is applied on a large } \\
\text { scale } \\
\text { - where large system approaches are adopted in smaller scale situations, } \\
\text { such as centralised water supply for small towns }\end{array}$ \\
\hline 3 & $\begin{array}{l}\text { General Budget } \\
\text { Support }\end{array}$ & $\begin{array}{l}\text { Many donors are increasing the proportion of programme-based aid through } \\
\text { general budget support. Whilst this is a major methodological challenge for the } \\
\text { DAC that runs beyond the water sector, there is concern that the destination of } \\
\text { general budget support to the water sector is unreportable through the } \\
\text { disaggregated codes, leading to an interpretation that "aid for water is dropping". }\end{array}$ \\
\hline 4 & $\begin{array}{l}\text { Capacity } \\
\text { development that } \\
\text { directly supports } \\
\text { implementation }\end{array}$ & $\begin{array}{l}\text { Where context-specific capacity development is provided as a pre-cursor to } \\
\text { implementation, the outcome of which is improved service delivery }\end{array}$ \\
\hline 5 & $\begin{array}{l}\text { Assignment within } \\
\text { the other multi- } \\
\text { sector projects }\end{array}$ & $\begin{array}{l}\text { Projects with multiple objectives in relation to rural development and water } \\
\text { resources management }\end{array}$ \\
\hline 6 & $\begin{array}{l}\text { Use of the Policy } \\
\text { Development Code }\end{array}$ & $\begin{array}{l}\text { To address the possibilities of over-using the code as a "catch-all" for sector } \\
\text { projects; allocations to this code may be perceived as "untargeted". } \\
\text { Where policy support is provided as a prerequisite for improved project } \\
\text { implementation }\end{array}$ \\
\hline
\end{tabular}

Source: OECD Development Co-operation Directorate (2010a)

These points are addressed in the following section; issues 1 to 3 in Table 2 were identified as the most significant and are illustrated using examples drawn from the 13 case studies to illustrate how the reporters of statistical data determine the appropriate code.

\section{IMPLICATIONS}

\section{General points about reported data for the water sector}

The guiding point that determines the reporting code for the water supply and sanitation components of a project or programme is the intention of the donor at the point of outflow (as expressed in the funding agreement). This is because the DAC CRS statistical system is conceived as a means to measure donors' financial outflows to developing countries and 
multilateral organisations. It is also possible to record donors' intentions (specific geographical or sector focus) and practices (aid modality or tying of aid). In order to be able to give a clear and compatible basis for analysis of donors' policy intentions and practices, it is important for users of OECD DAC statistical data to appreciate that donors adhere to this point of measurement and do not try to simultaneously measure the end use of funds.

The ease with which donors can disaggregate reporting using the new CRS Codes is a function of their individual internal management information and reporting systems. Some donors are able to disaggregate projects into a number of different components and assign each component an appropriate 140 Purpose Code. Other donors' systems only permit the assignment of a single Purpose Code to each project.

\section{Disaggregating water and sanitation data}

Within an integrated water and sanitation project, disaggregated reporting of water and sanitation can only be done where the individual donor's reporting system is able to identify this disaggregation. Otherwise, donors will report the ODA using the aggregated codes 14020 (large systems) or 14030 (basic systems).

Another commonly occurring situation is the need to disaggregate and report water and sanitation activities that are sub-components in a project that is predominantly in another sector, for example health. Again, the ability to report and capture such activities depends on the donor's internal reporting system. This is illustrated in Example 1.

\section{Example 1 Support to UNICEF Child Survival and Development Programme, Central African Republic}

\section{Description}

The project goal is to impact on child survival, growth and development; it is primarily a basic health sector project where the donor is supporting UNICEF.

\section{Project objectives}

“...(a) scale-up high impact health/nutrition interventions among under-five children, pregnant/lactating women; (b) improve young child survival, growth and development practices; (c) improve the access of rural population to safe water and to basic sanitation; (d) policy improvement; (e) assist populations affected by different crises in health, nutrition, water supply, hygiene and sanitation, according to CCC and cluster approach"

- The project contains a water and sanitation (140) component that is rural and clearly aimed at basic systems

\section{Budget allocations}

- The donor's reporting system allows the various project components to be identified, with $24 \%$ of the budget assigned to the safe water and sanitation component.

- The budget does not indicate any disaggregation between water \& sanitation.

- Code 14030 would be assigned to this component of the project.

\section{Implications}

The donor's reporting system enables a specific sub-project for water and sanitation to be reported separately under code 14030; however, further disaggregation between water supply and sanitation is not possible. If the donors' systems do not permit separate reporting of subproject components, the entire project would be recorded as a basic health project using 
reporting code 122 and the water and sanitation components would not be separately captured.

\section{Definition of 'large' and 'basic' water \& sanitation projects}

Donors on the consultative group consistently identified two specific problems concerning the interpretation of the terms 'large' and 'basic' in the CRS purpose codes.

- The tendency to interpret data according to geographic status assuming that 'urban equals large and rural equals basic'; this is misleading.

- The role of the type of the technology and the scale at which it is applied.

The distinction between 'large' and 'basic' is based on the type of technology adopted in accordance with the definitions for the various sub-sectors in Table 1 with the following clarification concerning the associated management systems that are necessary in order for the technologies to function:

- 'Large' involves technologies that require centralised management, operation and maintenance.

- 'Basic' involves technologies that can be managed, operated and maintained at a household, neighbourhood or community level.

The scale at which a project operates, or the coverage it aims to achieve, does not in itself determine whether the project is reported as large or basic. Example 2 illustrates the case of a basic urban sanitation programme being implemented using household and community based facilities. Examples 3 and 4 from small towns projects illustrate how the nature of the management system for the technologies involved can be a clear determinant of whether the project is reported as large or basic. The important implication is that there is no direct association between the nature of the ODA as "large" or "basic" and the typologies of "urban", "rural" and "small town".

These points are particularly significant given that it is a distinction to which those interpreting the data may often draw attention.

\section{Example 2: Environmental Health, Bangladesh}

\section{Description}

Improvements to water supply, sanitation and hygiene in both rural and urban areas.

\section{Project objectives}

Sustainable improvements in hygiene behaviour and reduction in exposure to water and environmental sanitation risks for poor rural and urban communities in challenging geographical, socio-economic and technical contexts in Bangladesh.

- The project is integrated, with a mix of urban, rural, water and sanitation.

\section{Budget allocations}

- The budget is disaggregated into three sub-programmes for urban, rural and advocacy.

- The budget does not disaggregate further between water, sanitation or hygiene promotion and the project description gives no indication as to what the disaggregation might be. The sub-projects will therefore be assigned to either 14020 (large) or 14030 (basic), as it is not possible to disaggregate into $14021 / 22$ or $14031 / 32$.

Technical appraisal: urban component 
“...connections for community water points or water kiosks will be provided by local authorities from their existing supply mains. In peri-urban and district town areas where separate supplies are required, deep-set lift hand pumps with above ground storage will be used to supply water stands managed by NGO partners or communities themselves"

- This contains a mix of simple extensions to the water supply system, but with the provision for small locally managed supplies; that is, basic water supply.

"...In urban areas, where access to land is restricted, cluster latrines or sanitation blocks are constructed. The programme promotes the construction of latrines in households (subsidyfree), public places, public institutions and schools."

- There is no provision for centralised systems and the proposed improvements comprise basic sanitation.

\section{Technical appraisal: rural component}

"...Water supply options include: shallow and deep tube wells; gravity flow piped water systems; tap stands; infiltration galleries and rainwater harvesting schemes"

"...Latrines in rural areas are normally of simple pit type"

- The rural component is clearly for basic water and basic sanitation systems.

Therefore, code 14030 is assigned to the entire project;

\section{Implications}

A project that operates on a very large scale can be 'basic'. It is the nature of the technology and its associated systems that distinguishes between 'large' (14020) and 'basic' (14030), not the scale of application. The urban/rural division is not used as a proxy for large and basic systems; and not all urban water projects are large.

\section{Example 3 Sanitation in small towns}

\section{Description}

The project provides support to sanitation in four towns in Mozambique involving a publicprivate partnership.

\section{Project objectives}

"..Contributing to the MDG7 (sanitation and hygiene) by realising improved water and sanitation services."

The project outputs include

"..strengthening the organisation of the Sanitation Department...of the four cities; access to improved sanitation facilities enlarged by $25 \%$.... as a direct realization of sanitation facilities at public places including schools and markets. Indirectly the improved access is caused by information and technical support at household-level....

- The project is related to sanitation and will be reported as either 14022 or 14032.

- The project contains a mix of elements that are necessary to implement a good sanitation programme including organisational capacity building, sanitation promotion, hygiene behaviour change; the budgets and donor's reporting system do not distinguish between these elements and the choice of purpose code is not necessarily clear cut. 
- This does not involve large systems, so the use of 14022 can be discounted.

- It is therefore a case of identifying the predominant theme. This relates to the implementation of sanitation-related activities and the majority of interventions are covered under the definitions of basic sanitation.

- Code 14032 is assigned to the project.

\section{Implications}

Basic sanitation projects do not necessarily involve donor funds being used for direct construction of household latrines; the primary focus is often on promotional activities that lead to creation of demand, and on developing local capacity.

The physical and demographic characteristics of small towns are not used as a proxy for deciding whether systems are large or basic.

\section{Example 4 Water Supply in small towns}

\section{Description}

The project aims to increase water availability, water quality and improve service quality.

\section{Project objectives}

"...to increase water production, increase transmission capacity, provide sufficient water storage"

The project outputs include

"..construction of the associated physical infrastructure of intake works, pumps, pipelines and storage reservoirs."

The project is concerned with centralised large scale water supply infrastructure; code 14021 is assigned to the project.

\section{Implications}

Along with Example 3, this illustrates that the small town context can involve both large and basic projects.

\section{The transition to programme based aid}

Many donors are moving away from funding specific projects and are increasing the proportion of programme based aid through budget support in accordance with the Paris Declaration on Aid Effectiveness (OECD Development Co-operation Directorate 2005). General budget support is covered in the DAC5 code 510, whereas sector budget support is reported under the specific sector code. As aid modalities become more programme-based in character, only a proportion of ODA going to water supply and sanitation can actually be identified at the point of outflow of funds from the donors. The main criterion that determines the assignment of sector codes for programme based aid (and the level of disaggregation within those codes) is the practice of individual donors on earmarking of ODA. Earmarking refers both to a legally binding conditionality on the use of funds and also to the explicit intention by the donor that the funds be used for a specified purpose.

The transition from project to programme support may not be clear-cut especially when this happens gradually through several planned stages in a relationship between a donor and 
recipient country; difficulties may also arise with reporting between different aid modalities and sector codes. Example 5 illustrates this transition.

\section{Example 5:Sector funding transition}

\begin{tabular}{|c|c|c|c|c|}
\hline Period & $\begin{array}{l}\text { Type of aid } \\
\text { (modality) }\end{array}$ & Sector Code & Objective & Comments \\
\hline 2002 & $\begin{array}{l}\text { Project } \\
\text { (C01) }\end{array}$ & 14010 & $\begin{array}{l}\text { Extension of existing } \\
\text { institution \& capacity } \\
\text { building (Technical } \\
\text { Support Unit Kabale) }\end{array}$ & $\begin{array}{l}\text { Institutional development and } \\
\text { capacity building become } \\
\text { predominant components. Sector } \\
\text { code is changed from that used } \\
\text { for pre-extension activities } \\
(14020)\end{array}$ \\
\hline 2004 & $\begin{array}{l}\text { Pooled } \\
\text { funding } \\
(\mathrm{CO} 1))\end{array}$ & 14030 & $\begin{array}{l}\text { Contribution to Joint Water } \\
\text { Supply \& Sanitation } \\
\text { Programme Support } \\
\text { (JWSSPS), earmarked for } \\
\text { operation and } \\
\text { maintenance support } \\
\text { structures for rural WSS } \\
\text { systems }\end{array}$ & $\begin{array}{l}\text { Contribution to sector programme } \\
\text { through joint fund, but earmarked } \\
\text { for specific components/activities }\end{array}$ \\
\hline 2008 & $\begin{array}{l}\text { Pooled } \\
\text { funding } \\
\text { (B04) }\end{array}$ & 14010 & Contribution to JWSSPS & $\begin{array}{l}\text { Unearmarked contribution to } \\
\text { sector programme through joint } \\
\text { fund }\end{array}$ \\
\hline 2009 & $\begin{array}{l}\text { Pooled } \\
\text { funding } \\
\text { (CO1) }\end{array}$ & 14031 & $\begin{array}{l}\text { Contribution to JWSSPS } \\
\text { for WSDF Northern } \\
\text { Uganda - }\end{array}$ & $\begin{array}{l}\text { Contribution to sector programme } \\
\text { through joint fund, but earmarked } \\
\text { for specific components/activities }\end{array}$ \\
\hline 2010 & $\begin{array}{l}\text { Sector } \\
\text { budget } \\
\text { support } \\
\text { (A02) }\end{array}$ & 14010 & $\begin{array}{l}\text { Contribution to JWSSPS } \\
\text { and sector budget support } \\
\text { for Water \& Sanitation }\end{array}$ & $\begin{array}{l}\text { Contribution to WSS sector } \\
\text { programme, various components, } \\
\text { mix of modalities (largest being } \\
\text { Sector Budget Support) }\end{array}$ \\
\hline \multicolumn{5}{|c|}{ Implications } \\
\hline $\begin{array}{l}\text { This } \\
\text { supp } \\
\text { supp }\end{array}$ & . & .II & e of reporting codes to & $\begin{array}{l}\text { flect this transition in a donor's } \\
\text { ictivity transforms into a budget } \\
\text { udget support may be most } \\
\text { cy' code } 14010 \text {. }\end{array}$ \\
\hline
\end{tabular}

\section{Other issues in assigning appropriate purpose codes}

Reporters of statistical data pay attention to uncertainties that may arise in assigning projects to the specific reporting codes, as illustrated by the following situations.

1. Reporting capacity development projects: project descriptions for training and capacity development often place strong emphasis on implementation and the improved results and outcomes in service delivery which arise as a consequence of increasing the capacity of local partner projects and local government departments. However, it is the intention of the donor 
at the point of outflow of the ODA that determines the reporting code, not the eventual outcomes of improved water, sanitation and hygiene service delivery. Capacity development is reported through purpose code 14081.

2. The need to assign a single code to a project that has distinct sub-components where the donor's own reporting system does not permit sub-division of the project for reporting purposes. For example, this can occur with small scale rural infrastructure projects where the first issue may be to determine whether the project is reported under purpose codes for water (140) or agriculture (311). Having established that the primary purpose was water, several cases were encountered where the distinction between water resources conservation (14015) and river basins' development (14040) were difficult to make within rural development projects, in which case a detailed investigation of the budget distribution is necessary.

\section{CONCLUSIONS}

Recent changes have been made to the reporting of ODA for the water sector, which from 2010 onwards disaggregates between aid flows for water supply and aid flows for sanitation. This reflects developments in recent years which led to a change both in donors' activities and in reporting needs, which are now more adequately covered by the new reporting codes. In particular, the off-track nature of the MDG target for sanitation has been a strong driver for reporting disaggregated data for ODA for sanitation.

An important general point for users of the reported data is that it is the intention of the donor at the point of outflow of funds that determines the reporting code. It is an input measure that cannot be used to infer outputs or outcomes in terms of the likely results of improved service delivery.

There are clear limits and constraints on the extent to which ODA for water supply and sanitation can realistically be disaggregated.

1. Donors may design integrated water and sanitation projects that deliberately do not prescribe how the funds should be allocated between subsectors a priori; thus the donor cannot disaggregate ODA flows at the time of reporting.

2. The ability of a donor to disaggregate the reporting of sub-components of a project or programme, e.g. between water supply and sanitation, depends entirely on the flexibility of its own management information systems.

3. A consequence of donors increasing the proportion of programme-based aid through budget support is that ODA that may be destined for the water sector is unreportable through the disaggregated codes at the point of outflow.

This implies that some aid for water and sanitation will not be captured at all and there will remain a proportion of aid going to sanitation that is not directly identifiable. Thus, users who are applying and interpreting the data will tend to under-report aid to both the water sector as whole and from those individual donors who may prioritise certain types of programme-based aid. Also, substantial volumes of sector ODA will continue to be reported using the aggregated codes for water supply and sanitation (14020 and 14030) or, in the case of sector budget support, through the more general code for policy development (14010).

Analysts frequently use the data to highlight the relatively low ODA for "basic" water supply and sanitation and it is important to note that the definitions of "large" and "basic" are applied in accordance with the nature of the technology and its associated management structures. The urban/rural division is not a proxy for large and basic systems. 
The CRS data are the most important primary source of information on aid flows to the sector and are regularly applied globally, regionally and nationally to track the trajectory of aid flows and support particular policy positions. Given the changes to the reporting of ODA, it would be helpful to the global community of users if a review could be undertake to determine how the revised purpose codes are being adopted by the reporters of the statistical data. The review could establish inter alia whether donors are using the opportunity to disaggregate ODA for sanitation from that for water and whether certain codes appear to be excessively used. These insights would be invaluable for the wider community of practice that relies on data available through the CRS.

\section{ACKNOWLEDGEMENTS}

The author thanks the Africa Working Group of the EU Water Initiative for their financial support and review of this research and the OECD Development Co-operation Directorate for their invaluable advice.

\section{REFERENCES}

EU Water Initiative Africa Working Group 2008 Working Together to Improve Aid effectiveness in the Water Sector, Africa Working Group - EU Water Initiative, European Commission, Brussels

GLAAS 2010 UN-Water Global Annual Assessment of Sanitation and Drinking-Water. WHO, Geneva, Switzerland.

OECD Development Co-operation Directorate 2010a OECD DAC Creditor Reporting System:

Guidance for the use of Water Supply and Sanitation Purpose Codes,

http://www.oecd.org/dac/aidstatistics/49819385.pdf [Accessed 13 July 2012]

OECD Development Co-operation Directorate 2010b The List of CRS Purpose Codes taking effect in 2011 reporting on 2010 flows. http://www.oecd.org/document/21/0,3746,en_2649 $34447 \quad 1914325$ 1_1_1_1,00.html [Accessed 18 November 2011]

OECD Development Co-operation Directorate 2009 Proposal to amend CRS purpose codes to enhance donor reporting in the water sector Working Party on Statistics, CD/DAC/STAT(2009)5, 5-6 May 2009, Paris.

OECD Development Co-operation Directorate 2005 Paris Declaration on Aid Effectiveness, Ownership, Harmonisation, Alignment, Results and Mutual Accountability Paris http://www.oecd.org/dataoecd/15/3/46874580.pdf [Accessed 28 November 2011]

OECD Development Co-operation Directorate n.d. StatExtracts Creditor Reporting System http://stats.oecd.org/Index.aspx?DatasetCode=CRSNEW [Accessed 18 November 2011]

WaterAid 2011 Off-track, off-target: Why investment in water, sanitation and hygiene is not reaching those who need it most. WaterAid, London

WELL 2005 Will it cost the earth? An overview of cost estimates for achieving the water and sanitation targets of the Millennium Development Goals WELL Briefing Note 9 WEDC, Loughborough University, UK.

WHO/UNICEF 2010 Progress on sanitation and drinking water: 2010 update. WHO/UNICEF Joint Monitoring Programme for Water Supply and Sanitation, WHO, Geneva, Switzerland 